\title{
STUDI PENAMBAHAN KEMIRI ( Aleurites Moluccanus ) TERHADAP MUTU DAN KEKENTALAN KECAP MANIS AIR KELAPA
}

\section{Mulono Apriyanto}

Pogram Studi Teknologi Pangan, Fakultas Pertanian, Universitas Islam Indragiri Jl. Propinsi parit 1. Tembilahan Hulu, Kabupaten Indragiri Hilir,Propinsi Riau

mulonoapriyanto71@gmail.com

\begin{abstract}
Abstrak
Penelitian ini berjudul Studi Penambahan Kemiri (Aleurites Moluccanus) terhadap Mutu dan Kekentalan Kecap Manis Air Kelapa. Tujuan penelitian ini adalah untuk mengatahui perlakuan terbaik dengan menambahkan kemiri (Aleurites Moluccanus) terhadap mutu kekentalan kecap air kelapa yang dihasilkan. Berdasarkan hasil penelitian dapat disimpulkan bahwa perlakuan terbaik. Terletak pada perlakuan A, dimana perlakuan A (Kemiri 5\% dan air kelapa $1 \mathrm{~kg}$ dengan hasil analisa kimia kadar air 25,914\%, Kadar lemak 9,673\%, Kadar kalium 0,03\%, Viskositas $3031,22 \%$, dengan skor uji organoleptik terhadap warna 3,20\%, Aroma $3,15 \%$, Rasa $3,25 \%$, dan tekstur $3,10 \%$.
\end{abstract}

Kata Kunci : Kemiri (Aleurites Moluccanus), Kecap, Air Kelapa

\section{PENDAHULUAN}

Indonesia merupakan negara penghasil kelapa terbesar di dunia dan diantara perkebunan kelapa ini $45 \%$ nya terdapat di propinsi Riau dengan luas perkebunan 589,81 ribu hektar dimana 429 ribu hektar perkebunan ini terdapat di kabupaten Indragiri Hilir yang merupakan daerah penghasil kelapa terbesar di Riau (Anonim, 2012), sehingga secara tidak langsung produksi air kelapa juga cukup berlimpah, namun pemanfaatannya masih kurang maksimal. Air kelapa yang terbuang dapat menimbulkan polusi asam asetat di sebabkan oleh karena fermentasi air kelapa, asam asetat yang terbentuk yang dapat menyebabkan gangguan pada kesuburan lahan pertanian (Rukmana, 2001).
Air kelapa merupakan air alamiah yang steril dan mengandung kadar kalium, khlor, serta klorin yang tinggi. Kandungan gizi yang terdapat pada 100 gram air kelapa yaitu kalori $17 \mathrm{~K}$, lemak 1 gram, kalsium $15 \mathrm{mg}$, fosfor $8 \mathrm{mg}$, besi 0,2 $\mathrm{mg}$, vitamin $1 \mathrm{mg}$, air 95,5 gram, dan protein 0,2 gram (Suparman, 2013). Sebagian penduduk sudah memanfaatkan air kelapa ini menjadi beberapa macam produk olahan, antara lain: cuka manis (vinegar), minuman air kelapa (kalengan), nata de coco, alkohol, dan bahan pengembang roti (shortening). Air kelapa juga dapat dijadikan sebagai bahan baku pada pembuatan kecap air kelapa baik kecap manis maupun kecap asin (Rukmana et al., 2001).

Kecap merupakan salah satu bahan makanan yang tidak asing bagi masyarakat Indonesia, sebab hampir setiap rumah tangga menggunakannya. 
Menurut Standar Nasional Indonesia (SNI 01-3543-1994) untuk kecap manis bahwa kecap tidak menggunakan penambahan bahan makanan lain dan tambahan makanan yang tidak diizinkan. Kecap manis ini mempunyai tekstur kental, berwarna coklat kehitamanhitaman, dan memiliki masa simpan yang relatif lama. Kecap manis sebagai salah satu bumbu masak secara umum berfungsi sebagai penyedap rasa masakan.

Kandungan zat gizi yang terdapat dalam kemiri adalah protein, lemak, dan karbohidrat. Kandungan kimia yang terdapat dalam kemiri adalah gliserida, asam linolet, palmitat, stearat, miristat, asam minyak, protein, vitamin $\mathrm{B} 1$, dan zat lemak. Bagian yang bisa dimanfaatkan sebagai obat adalah biji, kulit, dan daun.Buah kemiri digunakan sebagai bumbu masak tujuannya untuk bahan pengental pada masakan (Rukmana et al., 2001).

Pemamafaatan air kelapa di Kabupaten Indragiri Hilir belum begitu maksimal. Namun Air kelapa dapat diolah menjadi kecap manis. Dengan demikian salah satu cara pengembangan kecap manis air kelapa dengan diolah menjadi kecap. Masalah utama dalam pembuatan kecap manis air kelapa adalah kecap manis dari air kelapa kurang kental dibandingkan dari kecap manis dari kacang kedelai. Untuk meningkatkan kekentalan dari kecap air kelapa perlu ditambahkan bahan tambah seperti kemiri. Namun kosentrasi jumlah kemiri yang tepat untuk pengolahan kecap belum diketahui utuk menghasilkan kecap yang memiliki karakteristi dan mutu yang baik. Penelitian ini bertujuan mengetahui pengaruh penambahan kemiri terhadap mutu dan kekentalan kecap air kelapa yang dihasilkan.

\section{METODOLOGI}

\section{Alat dan Bahan}

Alat yang digunakan untuk pengolahan dalam penelitian ini adalah, panci, wajan,kompor, pisau, kain saring,dan botol. dan adapun alat yang digunakan untuk analisis adalah: neraca analitik,awan aluminium,oven,desikator, erlenmeyer,buret, pipet volumetric, pipet tetes, labu ukur, kondensor,dan pemanas listrik.

Bahan yang digunakan adalah air kelapa, gula merah,kemiri, bawang putih dan bawang merah, garam, daun salam dan daun jeruk, serta bumbu penyedap Adapun alat yang digunakan untuk analisa kimia adalah: Alkohol, N- Hesan $\mathrm{H}_{2} \mathrm{SO}_{4}, \mathrm{HCl}$.

\section{Rancangan Percobaan}

Rancangan percobaan ini dilakukan dengan menggunakan Rancangan Acak Lengkap (RAL) terdiri dari 4 perlakuan dan 3 ulangan dengan pola perlakuan $4 \times 3$ sehingga diperoleh 12 unit percobaan, dengan perlakuan sebagai berikut :

A. $5 \% / \mathrm{kemiri} /$ berat air kelapa

B. $10 \% / \mathrm{kemiri} /$ berat air kelapa

C. $15 \% / \mathrm{kemiri} /$ berat air kelapa

D. $20 \% /$ kemiri/ berat air kelapa

\section{Parameter yang Dianalisis}

Parameter mutu yang dianalisa adalah kadar air, viskositas dan kadar lemak (Sudarmadji et al., 1997).

\section{HASIL DAN PEMBAHASAN}

\section{Kadar Air Kecap}

Analisa kadar air pada pengolahan kecap manis air kelapa dilakukan untuk mengatahui jumlah kandungan kadar air yang terdapat pada kecap manis air kelapa tersaji pada tabel 1 . Tabel 1 menunjukkan bahwa kandungan kadar air pada kecap manis air kelapa berkisar 
antara $12,19 \%$ - 25,914\%. Kandungan kadar air tertinggi terdapat pada perlakuaan A $(5 \%$ kemiri/berat bahan) dengan skor $25,914 \%$ dan kadar air terendah pada perlakuan B (10\% kemiri/ berat bahan) dengan skor $12,19 \%$.

Tabel 1.Rata-rata Kadar Air terhadap Kecap Air Kelapa.

\begin{tabular}{|l|l|}
\hline \multicolumn{1}{|c|}{ Perlakuan } & Kadar air (\%) \\
\hline $\mathrm{B}=10 \%$ kemiri/berat bahan & $14,16 \mathrm{a}$ \\
\hline $\mathrm{C}=15 \%$ kemiri/berat bahan & $17,94 \mathrm{~b}$ \\
\hline $\mathrm{D}=20 \%$ kemiri/berat bahan & $23,37 \mathrm{bc}$ \\
\hline $\mathrm{A}=5 \%$ kemiri/berat bahan & $25,91 \mathrm{c}$ \\
\hline
\end{tabular}

Keterangan : Angka-angka pada tiap lajur yang diikuti oleh hurup kecil yang sama berarti berbeda tidak nyata pada tingkat kepercayaan 5\% menurut uji BNT.

Berdasarkan Tabel 1 terlihat bahwa kecap air kelapa yang terbaik adalah pada perlakuan A dengan kadar air 25,91 \% hal ini disebabakan karna semakin sedikit penambahan kemiri maka semakin tinggi tingkat kadar airya, adapun pada perlakuan ini tingkat kadar air yang terdapat pada kecap manis memenuhi standar sehingga kecap yang dihasilkan juga baik, hal ini sesuai hasil penelitian Fitandri (2011) mengenai HACCP pengolahan kecap. Seluruh nilai kadar air hasil penelitian masih dibawah ketentuan SNI untuk kadar air yang terkandung pada kecap manis air kelapa adalah $63 \%$, hal ini dapat disebabkan karena biji kemiri mempunyai kandungan lemak dan protein yang tinggi sehingga berakibat pada kekentalan dan kadar air yang menurun.
Kadar air dalam bahan pangan sangat mempengaruhi kualitas dan daya simpan dari bahan pangan tersebut. Oleh karena itu, penentuan kadar air dari suatu bahan pangan sangat penting agar dalam proses pengolahan maupun pendistribusian mendapat hasil yang baik.

\section{Viskositas Kecap}

Pada analisa viskositas menujukkan bahwa perlakuan penggunaan penambahan kemiri memberikan pengaruh tidak nyata terhadap tekstur kecap manis air kelapa, hal ini sejalan pernyataan Winarno (2004) bahwa kekentalan bisa dirasakan sensai kental, lembut, lengket, halus atau kasar berpasir dan lainya. Hasil pengamatan terhadap kekentalan kecap manis air kelapa tersaji pada Tabel 2.

Tabel 2. Rata-rata Penilaian Viskositas terhadap Kecap Manis Air Kelapa.

\begin{tabular}{|l|c|}
\hline \multicolumn{1}{|c|}{ Perlakuan } & Kadar Warna(\%) \\
\hline $\mathrm{D}=20 \%$ Kemiri / Berat Bahan & $3031,22 \mathrm{a}$ \\
\hline $\mathrm{B}=10 \%$ Kemiri / Berat Bahan & $1951,22 \mathrm{a}$ \\
\hline $\mathrm{C}=15 \%$ Kemiri / Berat Bahan & $1720,21 \mathrm{a}$ \\
\hline $\mathrm{A}=5 \%$ Kemiri / Berat Bahan & $1415,22 \mathrm{a}$ \\
\hline
\end{tabular}

Keterangan : Angka-angka pada tiap lajur yang diikuti oleh hurup kecil yang sama berarti berbeda tidak nyata pada tingkat kepercayaan 5\% menurut uji BNT 
Pada penelitian analisa vicositas ini perlakuan rata-rata yang terbaik adalah perlakuan D $(20 \%$ kemiri/berat bahan) dengan skor 3031,22\%. sedangkan pada perlakuan yang lain nilai viskositas kurang maksimal hal ini seperti yang dikatakan Fitandri (2011), semakin banyak kemiri yang ditambahkan pada kecap manis maka semakin tinggi tingkat kekentalan kecap manis.

Hasil penambahan kemiri dalam pembuatan kecap kental manis air kelapa menunjukan semakin tinggi persentase penambahannya berakibat pada peningkatan kekentalan kecap manisnya.

\section{Kadar Lemak}

Analisa kadar lemak pada pengolahan kecap manis air kelapa tersaji pada Tabel 3. Tabel 3 menunjukkan bahwa kandungan kadar lemak pada kecap manis air kelapa berkisar antara 9,673 - 15,803\%. Kandungan lemak tertinggi terdapat pada perlakuan C $(15 \%$ kemiri/berat bahan) yaitu $15,803 \%$ dan kadar lemak terendah terdapat pada perlakuan A $(5 \%$ kemiri/berat bahan) yaitu 9,673\%.

Tabel 3. Rata-rata Kadar Lemak terhadap Kecap Manis Air Kelapa.

\begin{tabular}{|l|l|}
\hline \multicolumn{1}{|c|}{ Perlakuan } & Kadar Lemak (\%) \\
\hline $\mathrm{A}=5 \%$ Kemiri / berat bahan & $9,67 \mathrm{a}$ \\
\hline $\mathrm{D}=20 \%$ Kemiri / berat bahan & $13,36 \mathrm{~b}$ \\
\hline $\mathrm{B}=10 \%$ Kemiri / berat bahan & $14,69 \mathrm{c}$ \\
\hline $\mathrm{C}=15 \%$ Kemiri / berat bahan & $15,80 \mathrm{~d}$ \\
\hline
\end{tabular}

Keterangan : Angka-angka pada tiap lajur yang diikuti oleh hurup kecil yang sama berarti berbeda tidak nyata pada tingkat kepercayaan 5\% menurut uji BNT.

Semakin banyak kemiri yang ditambahkan pada kecap air kelapa maka semakin meningkat juga kadar lemak yang terdapat pada kecap air kelapa hal ini sejalan dengan Fitandri (2011). Berdasarkan Tebel 3 terlihat bahwa lemak kecap air kelapa Pada perlakuan A kecap manis ini lemak yang dihasilkan tidak terlalu banyak karna penambahan kemiri yang ditambahkan hanya $5 \%$ / berat bahan sehingga kecap manis air kelapa yang didapatkan juga bagus dan cukup menurut standar SNI lemak yang terkandung dalam kecap manis ini yaitu $10 \%$.

\section{KESIMPULAN}

Berdasarkan hasil penelitian kecap manis air kelapa, bahwa penambahan kemiri memberikan pengaruh pada penurunan kadar air, meningkatnya kadar lemak dan meningkatnya viskositas sejalan dengan persentase kemiri yang ditambahkan.

\section{DAFTAR PUSTAKA}

Anonim, 2012. INHIL dalam angka. http://www.INHIL.go.id/ diakses 17 September 2016.

Fitandri, I. A. 2011. Mutu dan Penyusunan HAACP dengan Pengolahan Kecap Berbahan Baku IkanTongkol. Universitas Sebelas Maret. Surakarta. Surabaya.

Rukmana. 2001, Pembuatan Kecap air Kelapa. Kanisius. Yogyakarta.

Suparman. 2013. Pembuatan Kecap Ikan dengan Cara Kombinasi Hedrolisa dan Enzimatis dan Fermentasi, Jurnal Agrobitekper 2(1): 20-23. 
Rukmana, Rahmat dan Yuyun bahan pangan, liberty pres. Yuniarsih. 2001. Membuat Kecap, Yogyakarta.

Nira, Air Kelapa. Yogyakarta. Winarno, F. G. 2004. Kimia Pangandan Kanisius.

Gizi. Gramedia Pustaka Utama :

Sudarmadji, S., Bambang, $\mathrm{H}$ dan Jakarta

Suhardi., 1997. Prosedur analisa 